\title{
PEMBINAAN HIGIENE PERSONAL PADA PENJAMAH MAKANAN MENGGUNAKAN MEDIA CELEMEK DI KANTIN UNIVERSITAS ESA UNGGUL
}

\author{
Prita Dhyani Swamilaksita ${ }^{1 *}$, Rica Ardita Yumni², Mertien Sa'pang", \\ Putri Ronitawati ${ }^{4}$ \\ Jl. Arjuna Utara No. 9, Kebon Jeruk, Jakarta Barat, Telp (021) 56742231) \\ Email: prita.dhyani@esaunggul.ac.id
}

\begin{abstract}
ABSTRAK
Keberhasilan penyelenggaran makanan dilihat dari higiene perorangan penjamah makanan. Penjamah makanan diperlukan dalam proses penyelenggaran makanan, yang secara langsung berhubungan dengan makanan dan peralatan mulai dari tahap persiapan, pembersihan, pengolahan, pengangkutan sampai penyajian. Penjamah makanan yang tidak memperhatikan higiene perorangan dalam pengolahan makanan dapat menimbulkan kontaminasi bakteri pada makanan. Menurut Peraturan Menteri Kesehatan Republik Indonesia Nomor 1096/Menkes/Per/VI/2011 untuk mencegah penularan penyakit dan kontaminasi terhadap makanan yaitu antara lain tidak mengunyah, tidak merokok dan menggunakan alat pelindung diri seperti celemek, tutup kepala, sarung tangan, sepatu kedap air. Makanan yang tidak dikelola dengan baik dan benar oleh penjamah makanan dapat menimbulkan penyakit. Kegiatan abdimas ini dilakukan untuk membina personal higiene di kantin universitas esa unggul dengan harapan selain peningkatan pengetahuan, perilaku pengggunaan APD pada penjamah makanan dapat diterapkan sehingga penyediaan makanan di kantin Universitas Esa Unggul dapat terjamin kemanannya. Metode yang digunakan dalam kegiatan sosialisasi adalah metode ceramah menggunakan media celemek. Sasaran pada kegiatan ini seluruh penjamah makanan yang menjual makanannya di kantin Universitas Esa Unggul yang pada saat pelaksanaan berjumlah 10 orang. Hasil kegiatan meninjukan bahwa media celemek ini cukup efektif dalam meningkatkan pengetahuan dan merubah perilaku penjamah makanan. Sehingga perlu dilaksanakan kegiatan ini secara rutin dan konsisten untuk menjaga kepatuhan dalam pengaplikasian personal higiene dalam penyediaan makanan.
\end{abstract}

Kata Kunci: Higiene Personal, Celemek, Pembinaan Kantin, Kemananan Makanan, Penjamah Makanan

\section{ABSTRACT}

The success of food services is seen from the personal hygiene of food handlers. Food handlers are needed in the process of food handling, which is directly related to food and equipment from the preparation, cleaning, processing, distribution to serving stages. Food handlers who do not pay attention to personal hygiene in food processing can cause bacterial contamination of food. According to the regulation of the minister of health of the Republic of Indonesia number 1096/menkes/per/VI/2011 to prevent transmission of disease and contamination of food, such as not chewing, not smoking and using personal protective equipment such as aprons, headgear, gloves, waterproof shoes. Foods that are not properly and properly managed by food handlers can cause illness. This activity is carried out to foster personal hygiene in the canteen of Esa Unggul University with the hope that in addition to increasing knowledge, the behavior of using PPE in food handlers can be applied so that the provision of food in the canteen of Esa Unggul University can be guaranteed security. The method used in socialization activities is the lecture method using apron media. The target of this activity is all food handlers who sell their food in the canteen of Esa Unggul University, which at the time of implementation amounted to 10 people. The results showed that this apron media was quite effective in increasing knowledge and changing the behavior of food handlers. So that this activity needs to be carried out routinely and consistently to maintain compliance in the application of personal hygiene in the provision of food.

Keywords: Personal Hygiene, Apron, Canteen Improvement, Food Safety, Food Handlers 


\section{PENDAHULUAN}

Penyelenggaraan makanan yang higiene dan sehat menjadi prinsip dasar penyelenggaraan makanan institusi (Fatmawati, et al., 2013). Keberhasilan penyelenggaran makanan dilihat dari higiene perorangan penjamah makanan (Edinda \& Adi, 2016). Penjamah makanan di perlukan dalam proses penyelenggaran makanan, yang secara langsung berhubungan dengan makanan dan peralatan mulai dari tahap persiapan, pembersihan, pengolahan, pengangkutan sampai penyajian (Kemenkes RI, 2003). Penjamah makanan yang tidak memperhatikan higiene perorangan dalam pengolahan makanan dapat menimbulkan kontaminasi bakteri pada makanan (Meikawati 2010).

Menurut Peraturan Menteri

Kesehatan Republik Indonesia Nomor 1096/Menkes/Per/VI/2011 untuk mencegah penularan penyakit dan kontaminasi terhadap makanan yaitu antara lain tidak mengunyah, tidak merokok dan menggunakan alat pelindung diri seperti celemek, tutup kepala, sarung tangan, sepatu kedap air. Makanan yang tidak dikelola dengan baik dan benar oleh penjamah makanan dapat menimbulkan penyakit. Kejadian suatu penyakit yang disebabkan oleh makanan di Indonesia cukup besar, terlihat dari hasil Survei Konsumsi Makanan Individu (SKMI) Tahun 2014 yang melaporkan sekitar 200 laporan Kejadian Luar Biasa (KLB) yang terjadi tiap tahunnya (Arisanti, Indriani, dan Wilopo 2018). Kemenkes RI (2013) menyatakan bahwa $60 \%$ penyebab KLB diduga disebabkan oleh bakteri dan angka dari pleaporan 429 kasus yang terjadi di tahun 2010 diperkirakan jauh lebih besar karena jumlah provinsi yang memberikan laporan hanya $63 \%$. Statistik penyakit bawaan makanan yang ada di berbagai negara industri saat ini menunjukkan bahwa $60 \%$ dari kasus yang ada disebabkan oleh buruknya teknik penanganan makanan, dan terjadi kontaminasi pada saat disajikan di Tempat Pengelolaan Makanan (TPM).
Sangat minimnya pengetahuan para penjaja makanan mengenai cara mengelola makanan dan minuman yang sehat dan aman akan menambah besar resiko kontaminasi makanan dan minuman yang dijajakannya. Makanan dan minuman yang tercemar E. coli dapat menimbulkan penyakit yang pada gilirannya dapat mengganggu proses belajar mengajar (Ningsih 2014).

Salah satu faktor yang menyebabkan kontaminasi adalah rendahnya pengetahuan penjamah makanan dalam kebersihan diri dan penggunaan APD (Yunus 2015). Tingkat pendidikan membawa wawasan atau pengetahuan, seseorang yang berpendidikan lebih tinggi akan mempunyai pengetahuan yang lebih luas dibandingkan dengan seseorang yang tingkat pendidikannya lebih rendah. Pengetahuan penjaman makanan yang rendah akan mempengaruhi kepatuhan penjamah makanan pada saat proses pengolahan (Notoatmodjo 2014).

Hasil penelitian Fatmawati (2013), meneliti tentang perilaku higiene pengolahan makanan berdasarkan pengetahuan tentang higiene mengolah makanan dalam penyelenggaran makanan di Pusat Pendidikan dan Pelatihan Olahraga Pelajar Jawa Tengah yang berjumlah 6 orang menunjukan bahwa 3 orang responden ( $50 \%$ ) sudah mempunyai pengetahuan yang benar tentang higiene seorang pengolah makanan saat bekerja. Namun 3 orang (50\%) tenaga pengolah makanan masih memiliki pengetahuan dengan kategori sedang, hal ini menunjukkan bahwa 50 $\%$ pengolah makanan belum mengetahui dengan benar tentang higiene pengolah makanan. Pengetahuan penjamah makanan dikantin SMA Muhammadiyah 2 surabaya dalam kategori cukup dengan nilai $54,25 \%$ sedangka sikap penjamah makanan dengan nilai $3,3 \%$ bahwa tingkat pengetahuan yang kurang dapat mempengaruhi hygiene pada saat mengolah makanan (Avrilinda, 2016).

Berdasarkan latar belakang tersebut maka kegiatan abdimas ini 
dilakukan untuk membina personal higiene di kantin universitas esa unggul dengan harapan selain peningkatan pengetahuan, perilaku pengggunaan APD pada penjamah makanan dapat diterapkan sehingga penyediaan makanan di kantin Universitas Esa Unggul dapat terjamin kemanannya.

\section{METODE}

\begin{tabular}{llr}
\multicolumn{2}{c}{ Pelaksanaan } & sosialisasi \\
mengenai & pentingnya & higiene \\
personalpada & penjamah makanan di
\end{tabular}
kantin Universitas Esa Unggul dilaksanakan pada tanggal 26 September 2019. Adapun metode yang digunakan dalam kegiatan sosialisasi adalah menggunakan media bantuan yaitu celemek. Sasaran pada kegiatan ini seluruh penjamah makanan yang menjual makanannya di kantin Universitas Esa Unggul yang pada saat pelaksanaan berjumlah 10 orang.

Secara teknis, pelaksanaan kegiatan Abdimas yaitu:

1. Persiapan. Pada tahap persiapan ini dilakukan untuk Focus Discussion Group untuk mengetaui sejauh mana pengetahuan dan bagaimana aplikasi personal higiene pada penjamah makanan di esa unggul. Berdasarkan pengamatan diperoleh temuan bahwa penjamah makanan di esa ungul belum menggunakan alat pengaman diri (APD) yang umumnya digunakan untuk menjamin keamanan makanan seperti topi, celemek, sarung tangan, penutup mulut, dan alas kaki.

2. Pelaksanaan kegiatan. Pelaksanaan kegiatan yang dilakukan yaitu pemaparan materi yang meliputi item yang harus di aplikasikan pada personal higiene dan bagaimana tahapan pemakaian dalam APD.

3. Evaluasi kegiatan. Evaluasi kegiatan dilakukan dengan melihat feedback yang berupa aktivitas Media Celemek Di Kantin Universitas Esa Unggul tanya jawab setelah pemaparan materi dilakukan. Selain itu, hasil evaluasi akan dilaporkan dalam bentuk laporan dan dipublikasikan dalam jurnal atau temu ilmiah serta dijadikan dasar untuk pelaksanaan berikutnya.

\section{HASIL DAN PEMBAHASAN}

Pelaksanaan kegiatan Abdimas yang dilaksanakan pada 26 September 2019 ini dibuka secara langsung oleh Ibu Putri Ronitawati, S.KM, M.Si, RD selaku Dosen Ilmu Gizi, Universitas Esa Unggul dengan memaparkan materi pembuka mengenail higiene dan sanitasi kantin. Setelah itu, dilanjutkan dengan pemaparan mengenai personal higiene menggunakan media celemek. Pada saat kegiatan berlangsung, seluruh penjamah makanan yang hadir berjumlah 10 orang, dimana pada saat tahap persiapan diketahui bahwa seluruh penjamah makanan belum ada yang memenuhi standar personal higiene yang paling minimum yaitu menggunakan APD seperti topi, celemek, sarung tangan, penutup mulut, dan alas kaki yang tertutup. Selain itu sebelum kegiatan sosialisasi dilakukan pretest untuk mengukur pengetahuan mereka akan personal higiene. Berdasarkan hasil prestest diketahui bahwa seluruh penjamah makanan memiliki pengetahuan kurang dari 50\%.

Pengetahuan personal higiene pada penjamah makanan meningkat setelah diberikan sosialisasi, hal tersebut tergambar dari hasil posttest dan sesi tanya jawab. Berdasarkan hasil posttest diketahui bahwa seluruh penjamah makanan memiliki pengetahuan personal hygiene di atas 90\%, sedangkan berdasarkan feedback yang diperoleh selama kegiatan berupa aktifnya tanya jawab dan penyampaian kesan selama kegiatan menunjukan bahwa penjamah makanan tertarik dengan isi pesan yang ada di dalam celemek karena materi yang diberikan di dalam celemek mudah dipahami dengan penggunaan kata-kata 
yang jelas dan gambar mudah dipahami dijabarkan dalam bentuk simbol-simbol bahwa yang berwarna merah yang dilarang dan yang berwarna biru yang diperbolehkan, hal tersebut sehingga sebagian besar penjamah makanan sangat menyukai isi pesan yang terdapat pada

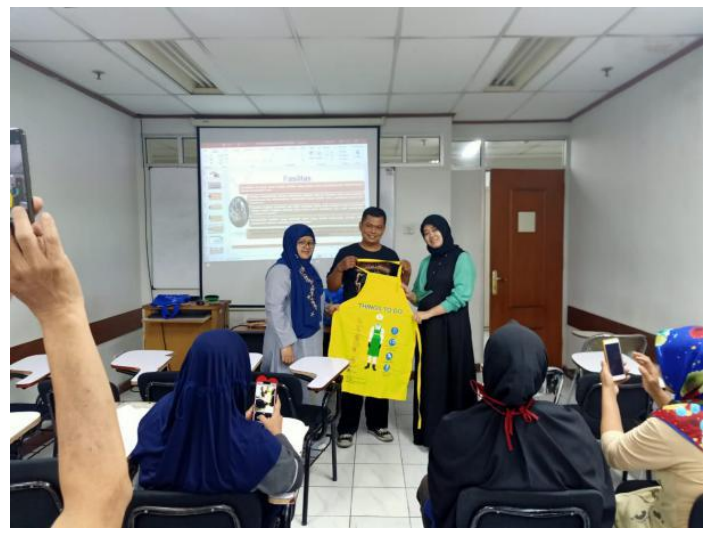

Gambar 1. Serah terima celemek kepada perwakilan penjamah makanan dalam kegiatan pembinaan personal higiene pada pejamah makanan

Materi yang disampaikan pada media celemek adalah materi yang terdapat dalam soal pretest dan posttest yaitu meliputi kebiasaan cuci tangan ketika sedang menyediakan makanan, menjaga kebersihan kuku, tidak menggunakan perhiasan ketika sedang bekerja atau menyediakan makanan, dan menggunakan APD standar seperti topi atau mengikat rambut, menggunakan celemek, sarung tangan, penutup mulut, dan alas kaki tertutup. Selain itu, pakaian yang digunakan harus bersih, tidak merokok pada saat bekerja, dan tidak berbicara saat menyediakan makanan kepada konsumen. Melalui pemaparan menggunakan media ini diharapkan perilaku positif seperti menggunakan APD standar dapat terus di aplikasikan agar makanan yang disajikan dapat terjamin aman.

Media bermanfaat menimbulkan minat sasaran, merangsang sasaran untuk meneruskan pesan pada orang lain, dan memudahkan penyampaian informasi. Reaksi yang dinyatakan sebagai sikap itu timbul yang didasari oleh proses evaluasi celemek. Pada media celemek warna yang digunakan warna kuning karena warna kuning salah satu warna yang menimbulkan awareness sehingga penjamah makanan tertarik untuk memakai celemek tersebut yang menimbulkan kesadaran.

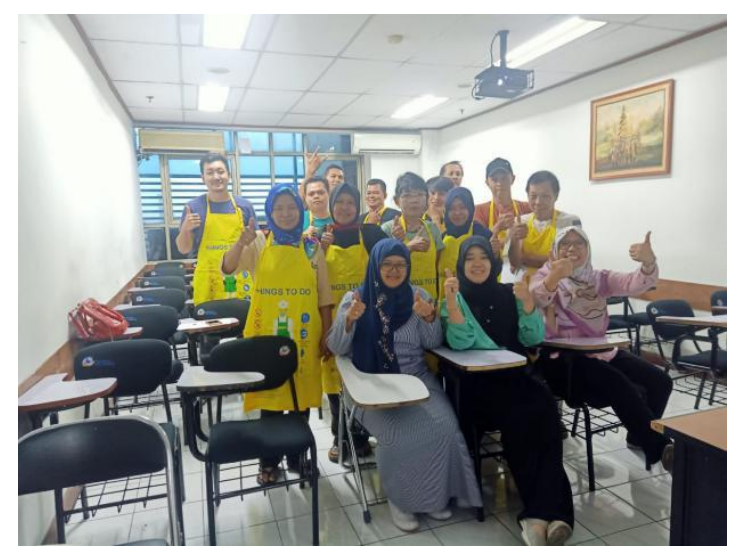

Gambar 2. Penutupan kegiatan pembinaan personal higiene pada pejamah makanan

dalam diri individu yang memberikan kesimpulan terhadap stimulus dalam bentuk nilai baik buruk, positif, negatif, menyenangkan tidak menyenangkan, sebagai potensi reaksi terhadap objek.

\section{SIMPULAN}

Kegiatan pembinaan personal higiene pada penjamah makanan perlu dilaksanakan secara rutin dan konsisten untuk menjaga kepatuhan dalam pengaplikasian personal higiene dalam pengelolaan makanan dan minuman. Berdasarkam kegiatan ini dapat diketahui bahwa penjamah makanan yang sebelumnya tidak tahu personal higiene menjadi tahu, baik dari item APD dan kegiatan seperti mencuci tangan, kebersian diri, dan menghindari rokok ketika bekerja. Berdasarkan feedback yang diperoleh terlihat bahwa penjamah makanan sangat antusias dengan kegiatan tersebut terlihat dari aktifnya tanya jawab dan memberikan penyataan kesediaan 
menggunakan celemek tersebut sebagai salah satu APD wajib selama bekerja. Oleh karena itu, bisa dikatakan media celemek ini cukup efektif dalam upaya meningkatkan pengetahuan dan merubah perilaku penjamah makanan.

\section{DAFTAR PUSTAKA}

1. Arisanti, Indriani, dan Wilopo. (2018). Kontribusi Agen Dan Faktor Penyebab Kejadian Luar Biasa Keracunan Pangan Di Indonesia: Kajian Sistematis. BKM Journal of Community Medicine and Public Health 34(3) : 99-106.

2. Avrilinda, S. M., \& Kristiastuti, D. (2016). Pengaruh Pengetahuan dan Sikap Terhadap Perilaku Higiene Penjamah Makanan di Kantin SMA Muhammadiyah 2 Surabaya. e-journal Boga, (2).

3. Edinda, A. M., \& Adi, A. C. (2016). Hubungan Pengetahuan Dengan Sikap Dan Higiene Perorangan (Personal Higiene) Penjamah Makanan Pada Penyelenggaran Makanana Asrama Putri. Media Gizi Indonesia, 120-126.

4. Fatmawati, S., Rosidi, A., \& Handarsari, E. (2013). Perilaku Higiene Pengolah Makanan Berdasarkan Pengetahuan Tentang Higiene Mengolah Makanan Dalam Media Celemek Di Kantin Universitas Esa Unggul Penyelenggaraan Makanan Di Pusat Pendidikan Dan Latihan Olahraga Pelajar Jawa Tengah. Jurnal Gizi, 2(2).

5. Kemenkes RI. (2003). Pedoman persyaratan hygiene sanitasi makanan jajanan. Jakarta: Kemenkes RI.

6. Kemenkes RI. (2013). Peraturan Menteri Kesehatan RI No 2 Tahun 2013 Tentang Kejadian Luar Biasa Keracunan Pangan, Jakarta.

7. Meikawati. (2010). Hubungan Pengetahuan dan Sikap Tugas Penjamah Makanan dengan Praktek Higiene dan Sanitasi Makanan di Unit Gizi RSJD Dr. AMINO Gondohutomo Semarang.. jurnal Kesehatan Masyarakat Indonesia.

8. Ningsih. (2014). Penyuluhan Hygiene Sanitasi Makanan dan Minuman, Serta Kualitas Makanan yang Dijajakan Pedagang di Lingkungan SDN Kota Samarinda. Jurnal Kesehatan Masyarakat, 10 (1) hal 64-72.

9. Notoatmodjo. (2014). Ilmu Perikaku Kesehatan. Jakarta: Rineka Cipta.

10. Yunus. (2015). Hubungan Personal Higiene dan Fasilitas 
Jurnal Pengabdian dan Pengembangan Masyarakat,

Vol 3 No 12020375 - 380

Sanitasi dengan Kontaminasi

Escherichia Coli Pada Makan di

Rumah Makan Padang Kota

Manado dan Kota Bitung .

JIKMU. 